\title{
Comparative Metal lon Binding to Native and Chemically Modified Datura innoxia Immobilized Biomaterials
}

\author{
Gary D. Rayson and Patrick A. Williams \\ Department of Chemistry and Biochemistry \\ New Mexico State University, Las Cruces, NM \\ USA
}

\section{Introduction}

Removal of toxic heavy metal ions from contaminated water is required to provide safe drinking water. This can be effected either within the waste stream at contaminate source or at point of use. Incorporation of remediation technologies at either location requires the removal of pollutants at parts per million and parts per billion concentrations from water containing more benign metal ions (e.g., $\mathrm{Ca}^{2+}, \mathrm{Mg}^{2+}$, and $\mathrm{Na}^{+}$) at concentrations three to six orders of magnitude higher. Materials derived from plants or microorganisms (e.g., algae and fungi) have been shown to enable the reduction of trace concentrations of heavy metal ions to below regulatory limits (Davis, et al., 2003).

Such nonliving biomaterials have been reported to have exhibit high capacity, rapid binding, and selectivity towards heavy metals (Drake and Rayson, 1996). It is postulated that functional groups native to the lipids, carbohydrates, and proteins found in the cell walls of the biomaterial are responsible for uptake (biosorption) of metal ions (GardeaTorresdey, et al., 1999; 2001; Drake and Rayson, 1996; Drake, et al., 1997; Kelley, et al., 1999). For biomaterials to become a commercially viable method of metal remediation and recovery these functional groups must be identified and their contribution to overall metal binding capacity quantified. Knowledge of such informaiton would allow either simple chemical alteration to the biomaterial, allowing for targeting of specific metals, or an enhancement of biomaterial metal binding.

Significant progress has been made to identify the chemical functionalities involved in the biosorption of numerous metal ions by a variety of plant and algal tissues (GardeaTorresdey, et al., 1999; 2001; Riddle, et al., 2002; Fourest and Volesky, 1996; Drake, et al., 1997;Jackson, et al., 1993). Several techniques have been reported to probe local chemical environments of biosorbed metal ions. These have included X-ray absorption (GardeaTorresdey, et al., 1999; Riddle, et al., 2002), lanthanide luminescence (Drake, et al., 1997; Serna, et al., 2010), and metal NMR (Xia and Rayson, 1996; 2002; Kelley, et al., 1999; Majidi, et al., 1990) spectroscopy. Analysis of total metal ion binding isotherm data modeling (Volesky, 2000) has also been described. Efforts to address the chemical heterogeneity of those biosorbed materials have also employed regularized regression analysis of isotherm data (Lin, et al., 1996). Additionally, these chemical intensities have been studied through selective removal of binding moieties by their reactive modification (Drake, et al., 1996). 
It has been shown that carboxyl groups present in the cell walls of nonliving biomaterials contribute to metal-ion binding (Gardea-Torresdey, et al., 1999; 2001; Riddle, et al., 1997; Kelley, et al., 1999). Our group has used a variety of methods(Lin, et al., 2002; Drake, et al., 1996; Xia and Rayson, 1995; Drake, et al., 1996; 1997) to characterize the binding groups present in the cell walls of Datura innoxia. This plant is a member of the Solanaceae plant family and native to Mexico and the southwestern United States. To minimize variability of cell types investigated, the cell-wall fragments used are cultured anther cells of the plant. This plant was selected for study because it is a heavy metal resistant perennial that is both tolerant of arid climates and resistant to herbivory (Drake et al., 1996).

Our group has concentrated primarily on nonviable biomaterials, specifically cell wall fragments from the cultured anther cells of Datura innoxia. The present study used frontal affinity chromatography with inductively coupled plasma optical emission spectroscopy (ICP-OES) detection for simultaneous monitoring both uptake and release of metal ions to both a chemically modified and native D. innoxia biomaterial (Williams and Rayson, 2003). The objective of the present study was to further investigate such sites through sequential exposure and subsequent stripping of three similar metal ions $\left(\mathrm{Cd}^{2+}, \mathrm{Ni}^{2+}\right.$, and $\left.\mathrm{Zn}^{2+}\right)$ to both a modified and the native biosorbents, thus to study the role of carboxylate furface functionalities on passive metal ion binding of this material.

It has been demonstrated (Drake, et al., 1996) that carboxylate-containing binding sites can be removed through the formation of the corresponding methyl esters by reaction with acidic methanol for 72 hours (Drake, et al., 1996). Undertaking a similar series of experiments with such a chemically modified sorbent enables the investigation of alternate binding sites.

\section{Materials and methods}

\subsection{Esterification of biomaterial}

The cultured anther cells from $D$. innoxia were washed and prepared as described elsewhere (Drake, et al, 1996; 1997). Only cell fragment aggregates with a mesh size greater than 200 (< $127 \mu \mathrm{m}$ ) were used for esterification. Following a method described elsewhere (Drake, et al., 1996), 10.0 grams of the biomaterial were suspended in $0.1 \mathrm{M} \mathrm{HCl}$ in methanol. The slurry was continuously heated at $60^{\circ} \mathrm{C}$ and stirred for 72 hours. The biomaterial was then recovered through vacuum filtration, rinsed three times with $16.0-\mathrm{M} \Omega$ water (Barnstead,Millipore Ultrapure), freeze-dried, and set aside for later immobilization.

\subsection{Immobilization of biomaterial}

In their native state, biomaterials have poor mechanical strength, low density, and a small particle size that can cause column clogging (Stark and Rayson, 2000). These characteristics can yield poor candidates for column-based water treatment applications. For this study native and modified $D$. innoxia biomaterials were each immobilized in a polysilicate matrix. The 40-60-mesh size fraction of the ground, and sieved immobilized biosorbents was then packed into columns. The process for immobilization has been described in detail elsewhere (Stark and Rayson, 2000).

Briefly, a suspension of 20 grams of the 100-200 mesh fraction of the washed biomaterial was generated with $300 \mathrm{~mL}$ of $5 \% \mathrm{v} / \mathrm{v}$ sulfuric acid adjusted to $\mathrm{pH} 2.0$ by addition of a $6 \%(\mathrm{w} / \mathrm{v})$ solution of $\mathrm{Na}_{2} \mathrm{SiO}_{3} \bullet 5 \mathrm{H}_{2} \mathrm{O}$. This suspension was stirred for 1 hour and the $\mathrm{pH}$ of the solution 
further raised to 7.0 by incremental addition of the $\mathrm{Na}_{2} \mathrm{SiO}_{3}$ solution. A gelatinous polymer formed at $\mathrm{pH}$ 7.0. The solution was stirred an additional 30 minutes, covered and stored at $4^{\circ} \mathrm{C}$ overnight. The resulting aqueous layer was removed. Excess sulfate ions were removed from the gel by successive washings with distilled deionized water until the aqueous phase failed a sulfate test using a few drops of a 1.0\% barium solution (as the nitrate salt). When no precipitate was visible, one final wash with the distilled deionized water was performed to ensure complete sulfate removal.

Remaining polymer was transferred to ceramic evaporating dishes and baked at approximately $100^{\circ} \mathrm{C}$ until completely dry. The immobilized D. innoxia biomaterial was then ground and sieved. The 40-60-mesh $(423-635 \mu \mathrm{m})$ particle size fraction was collected. Percent compositions of cell wall biomaterial were determined gravimetrically to be $64.6 \%$ and $75.3 \%$ for the native and modified materials, respectively.

\subsection{Biomaterial columns}

The columns used have been described elsewhere (Williams and Rayson, 2003) and were constructed in-house from Plexiglas ${ }^{\mathrm{TM}}$ tubing $\left(2.5 \mathrm{~cm}\right.$ in length and $3 \mathrm{~mm}$ i.d.). Teflon ${ }^{\mathrm{TM}}$ tubing (0.8-mm i.d.) was used for all column connections. Interface of the column to the ICPOES was accomplished by connecting the column outlet directly to the inlet of the crossflow type nebulizer using the minimum length of Teflon ${ }^{\mathrm{TM}}$ tubing $(15 \mathrm{~cm})$. Column effluent was monitored for each of 27 different metals simultaneously. Table 1 list the elements observed and their respective emission wavelengths.

\begin{tabular}{|c|c|c|c|c|c|}
\hline Element & Wavelength/nm & Element & Wavelength/nm & Element & Wavelength/nm \\
\hline $\mathrm{Na}$ & 589.00 & $\mathrm{Mg}$ & 279.00 & $\mathrm{Al}$ & 396.15 \\
\hline $\mathrm{Ca}$ & 317.90 & $\mathrm{Cr}$ & 267.70 & $\mathrm{Mn}$ & 257.60 \\
\hline $\mathrm{Fe}$ & 259.90 & $\mathrm{Ni}$ & 231.60 & $\mathrm{Cu}$ & 324.70 \\
\hline $\mathrm{Zn}$ & 213.80 & $\mathrm{Cd}$ & 228.80 & $\mathrm{Ag}$ & 328.00 \\
\hline $\mathrm{Sn}$ & 189.90 & $\mathrm{~Pb}$ & 220.30 & $\mathrm{Ba}$ & 493.40 \\
\hline $\mathrm{Sr}$ & 421.50 & $\mathrm{U}$ & 409.00 & $\mathrm{Y}$ & 371.00 \\
\hline $\mathrm{V}$ & 242.40 & $\mathrm{Mo}$ & 202.00 & $\mathrm{Co}$ & 228.60 \\
\hline $\mathrm{Si}$ & 251.60 & $\mathrm{As}$ & 193.60 & $\mathrm{Se}$ & 196.00 \\
\hline $\mathrm{Tb}$ & 350.97 & $\mathrm{Eu}$ & 381.97 & $\mathrm{Th}$ & 283.73 \\
\hline
\end{tabular}

Table 1. Elements and the corresponding emission wavelength used during monitoring of column effluents (elements of interests in this study indicated by boldface print).

Each column was packed with approximately $125 \mathrm{mg}$ of the immobilized D. innoxia material and flow tested using distilled deionized water. Once packed and tested for leaks, each column was exposed to $20 \mathrm{~mL}$ of 1.0-M HCl using a peristaltic pump (Model Rabbit, Rainin) $(1.0 \mathrm{~mL} / \mathrm{min}$ for $20 \mathrm{~min})$ and the effluent monitored for metals released from the biomaterial. Following the acid rinse, the columns were then exposed to $5 \mathrm{~mL}$ of distilled deionized water $(1.0 \mathrm{~mL} / \mathrm{min}$ for five minutes) to reestablish an ambient $\mathrm{pH}$ influent environment ( $\sim \mathrm{pH} 6.2)$.

These studies involved, initially, the exposure of a small column $(3.0 \mathrm{~mm}$ i.d., $10.0 \mathrm{~mm}$ in length) to an equimolar mixture of metal ions, specifically, $\mathrm{Cd}^{2+}, \mathrm{Zn}^{2+}$, and $\mathrm{Ni}^{2+}$, and exposure to solutions of each metal sequentially while continuously monitoring these (and other) metal species in the column effluent. 


\subsection{Frontal affinity chromatography with inductively coupled plasma atomic emission detection}

This technique has been described in detail elsewhere (Williams and Rayson, 2003). Briefly, the biomass packed column, having been exposed to $20 \mathrm{~mL}$ of $1.0 \mathrm{M} \mathrm{HCl}$ to remove any metals remaining on the biomaterial (effluent monitored by ICPAES), was exposed to $5 \mathrm{~mL}$ of $16 \mathrm{M} \Omega$, distilled-deionized water. The influent was a metal-ion solution, $0.1 \mathrm{mM}-0.2 \mathrm{mM}$, made from the nitrate salt of $\mathrm{Cd}^{2+}, \mathrm{Ni}^{2+}$, or $\mathrm{Zn}^{2+}$. Initially, the influent metal ion concentration increased as a step function.

Each influent was pumped through a column using a peristaltic pump (Rainin) at the rate of $\sim 1.0 \mathrm{~mL} \mathrm{~min}^{-1}$ to a cross-flow type nebulizer and Scott-type double-pass spray chamber of the ICP-OES spectrometer (Jarrell-Ash, AtomComp700). The biomaterial in each column was exposed to each metal solution for 50 minutes. The effluent was monitored and resulting break-through curves were recorded for each metal ion (Figures 1A-C). Following exposure to the column, bound metal ions were stripped from the column using each of two exposures to a $1.0 \mathrm{M} \mathrm{HCl}$ solution. The first 150 -second $(\sim 2.5 \mathrm{~mL})$ exposure removed approximately $98 \%$ of the metal ions on the column (Figure 1D). The second 20 minute ( 20 $\mathrm{mL})$ exposure removed the remaining $2 \%$. This was followed by a 5 minute $(\sim 5 \mathrm{~mL})$ rinse with distilled deionized water to return the $\mathrm{pH}$ to $\mathrm{f}$ the biomaterial to that of the natural water ( 6.2). Influent $\mathrm{pH}$ was not buffered to a predetermined $\mathrm{pH}$ to more accurately emulate conditions of a natural water supply within a remediation application.

With a three metal system there are six combinations that the metals can be sequentially exposed to the biomaterial (CdZnNi, CdNiZn, NiCdZn, NiZnCd, ZnCdNi, and ZnNiCd) and all six were performed on each column. Specifically, the $\mathrm{ZnNiCd}$ sequence involved

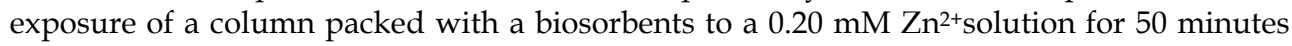
(Figure 1A). The influent was changed to a $0.20 \mathrm{mM} \mathrm{Ni}^{2+}$ solution for another 50 minutes (Figure 1B). Similarly, a $0.20 \mathrm{mM} \mathrm{Cd}^{2+}$ solution was pumped through the same column for an additional 50 minutes (Figure 1C). The column was then exposed to $1.0 \mathrm{M} \mathrm{HCl}$ for 2.5 and 20 minutes to remove all bound metal ions (Figure 1D).

Simultaneous exposure of the three metals at the same molar concentration was also undertaken for each column with both the native (Figure 2) and modified (not shown) biomaterials. All determinations were performed in triplicate with three separate columns packed with each individual biosorbent.

\section{Results and discussion}

\subsection{Binding capacities of native and modified $d$. innoxia}

Figure 1 illustrates a sequential $50-\mathrm{mL}$ exposure of $0.1 \mathrm{mM} \mathrm{Zn}^{2+}, \mathrm{Ni}^{2+}$, and $\mathrm{Cd}^{2+}$ to the native D. innoxia. Figure 2 shows the sequential $50-\mathrm{mL}$ exposures of $0.2 \mathrm{mM} \mathrm{Zn}^{2+}, \mathrm{Ni}^{2+}$, and $\mathrm{Cd}^{2+}$ to the modified biomaterial. Table 2 lists the observed binding capacities for the three metals to the modified $D$. innoxia reported in moles metal bound per gram of biomaterial for each replicate. The capacities reported are mass balance capacities, as the column effluent was monitored.

Simple statistical analysis using a t-test confirms the binding capacity of each metal to the biomaterial was decreased as expected. The position of the metal in the sequence was similarly indicated as affecting capacities in both the native and the modified biomaterial materials. Further statistical analysis indicated that not only the position in the sequence but 
the history of exposure appears to impact apparent steady state binding metal ion capacities of the biomaterial.
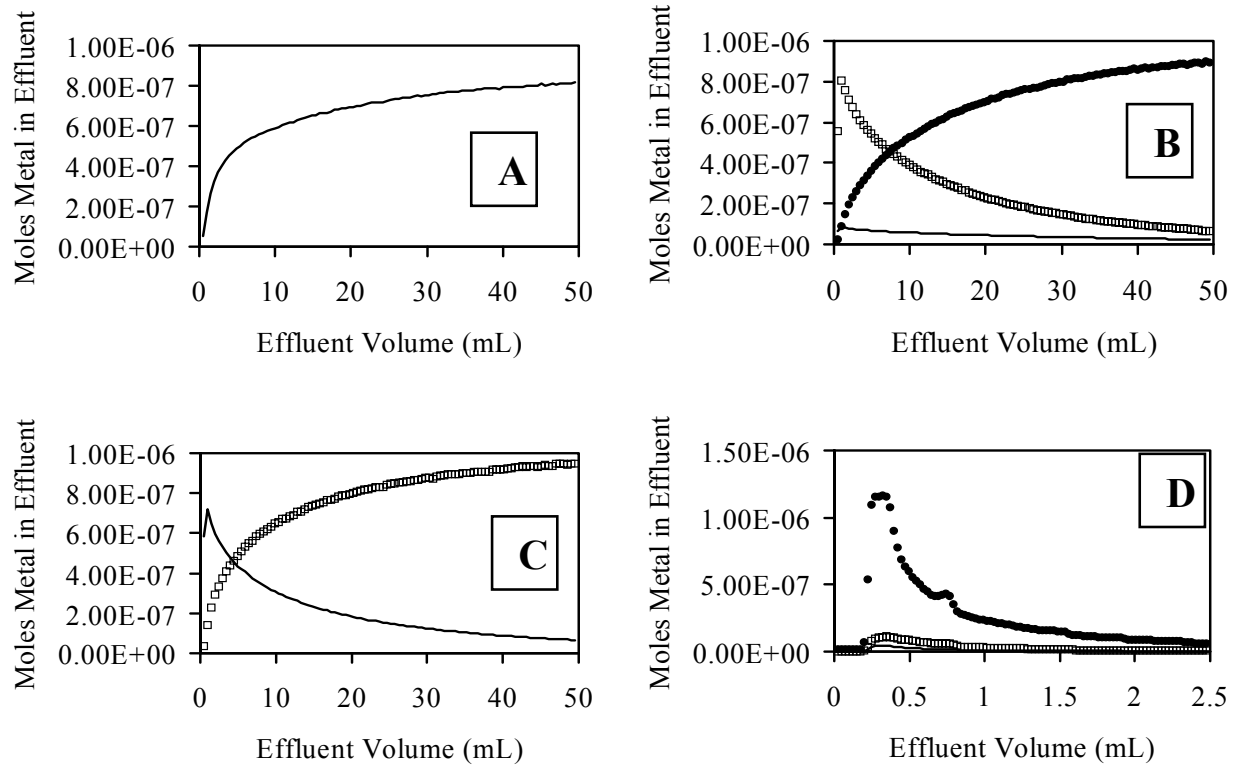

Fig. 1. Effluent profiles resulting from solutions of (A) $0.2 \mathrm{mM} \mathrm{Zn}^{2+}(-)$, (B) followed by 0.2 $\mathrm{mM} \mathrm{Ni}^{2+}(\square)$, followed by $0.2 \mathrm{mM} \mathrm{Cd}^{2+}(\bullet)$ pumped through a column packed with chemically modified D. innoxia.(D) Effluent profile of first $1.0 \mathrm{M} \mathrm{HCl}$ wash of the metal-laden material.

\subsection{Modified material three-metal sequential study}

Total amounts of metal bound to the native and modified materials at each stage of the sequence are listed in Table 2. Although the average amount of the fist metal ion bound was $24.5 \mu \mathrm{mol} \mathrm{g}-1$, the average total metal ion bound after exposure to the second and third metals was $31.0 \mu \mathrm{mol} \mathrm{g-1}$. This increase in the amount of metal captured by the biomass could be indicative of either the presence of metal ion-specific binding sites, or some degree of competitive metal ion binding.

Simultaneous exposure of the biosorbent material to an equimolar solution of all three metal-ions $(0.2 \mathrm{mM})$ was undertaken. Figure 2A shows the resulting effluent concentration profile. Even with a total metal ion concentration of $0.6 \mathrm{mM}$, the effluent concentration maximized at only $94 \%$ of the influent concentration (i.e., $0.19 \mathrm{mM}$ ). The modified biomaterial average capacity with simultaneous exposure was $41.72 \mu \mathrm{mol} \mathrm{g}{ }^{-1}$ biomaterial. Specifically, total amounts of metal ion bound were $13.24,14.17$, and $14.31 \mu \mathrm{mol} \mathrm{g}-1$ for $\mathrm{Ni}^{2+}$ $\mathrm{Zn}^{2+} \mathrm{Cd}^{2+}$, respectively. This suggests no significant binding preference of the $D$. innoxia cell material for these ions.

Figure $2 \mathrm{~B}$ shows the effluent concentration profile of the subsequent $1.0 \mathrm{M} \mathrm{HCl}$ metal-ion recovery/strip step. Total metal ion recovered from the two acid washes was $27.48 \mu \mathrm{mol} \mathrm{g-1}$. 
This included 7.68, 10.21, and $9.59 \mu \mathrm{mol} \mathrm{g}-1$ for $\mathrm{Ni}^{2+} \mathrm{Zn}^{2+} \mathrm{Cd}^{2+}$, respectively. Nickel recovery was lowest among the three ions (58.0\%), while cadmium and zinc recovered $67.0 \%$ and $72.1 \%$, respectively. This suggests the affinity of some of the $\mathrm{Ni}^{2+}$ binding sites were higher than those for each of the other two metal ions.

\begin{tabular}{c|c|c|c|c|c|c}
\hline Sequence & Column a & Column b & Column c & Average & Std. Dev. & \% RSD \\
\hline $\mathrm{Cd}$ & 28.26 & 22.63 & 25.49 & 25.46 & 2.56 & 10.05 \\
\hline $\mathrm{Ni}$ & 23.57 & 20.79 & 23.35 & 22.57 & 1.84 & 8.16 \\
\hline $\mathrm{Zn}$ & 24.56 & 24.88 & 26.76 & 25.40 & 1.57 & 6.16 \\
\hline $\mathrm{Cd} \mathrm{Ni}$ & 27.14 & 27.14 & 24.29 & 26.19 & 1.64 & 6.28 \\
\hline $\mathrm{Cd} \mathrm{Zn}$ & 30.33 & 24.57 & 24.51 & 26.47 & 3.34 & 12.62 \\
\hline $\mathrm{Ni} \mathrm{Cd}$ & 28.39 & 26.04 & 29.95 & 28.13 & 1.97 & 7.01 \\
\hline $\mathrm{Ni} \mathrm{Zn}$ & 29.72 & 25.95 & 25.57 & 27.08 & 2.29 & 8.47 \\
\hline $\mathrm{Zn} \mathrm{Cd}$ & 27.53 & 24.49 & 31.49 & 27.84 & 3.51 & 12.61 \\
\hline $\mathrm{Zn} \mathrm{Ni}$ & 25.99 & 26.09 & 27.66 & 26.58 & 0.94 & 3.52 \\
\hline $\mathrm{Cd} \mathrm{Ni} \mathrm{Zn}$ & 30.83 & 27.00 & 30.06 & 29.30 & 2.02 & 6.91 \\
\hline $\mathrm{Cd} \mathrm{Zn} \mathrm{Ni}$ & 27.89 & 24.21 & 27.54 & 26.55 & 2.03 & 7.64 \\
\hline $\mathrm{Ni} \mathrm{Cd} \mathrm{Zn}$ & 32.89 & 26.00 & 25.42 & 28.10 & 4.15 & 14.78 \\
\hline $\mathrm{Ni} \mathrm{Zn} \mathrm{Cd}$ & 21.63 & 24.57 & 27.69 & 24.63 & 3.03 & 12.29 \\
\hline $\mathrm{Zn} \mathrm{Cd} \mathrm{Ni}$ & 27.45 & 27.45 & 40.95 & 31.95 & 7.80 & 24.40 \\
\hline $\mathrm{Zn} \mathrm{Ni} \mathrm{Cd}$ & 26.27 & 23.75 & 23.62 & 24.55 & 1.49 & 6.09 \\
\hline
\end{tabular}

Table 2. Influent metal bound at each stage of the sequential exposure study. Values presented are given in $\mu$ moles metal per gram of modified biomaterial.
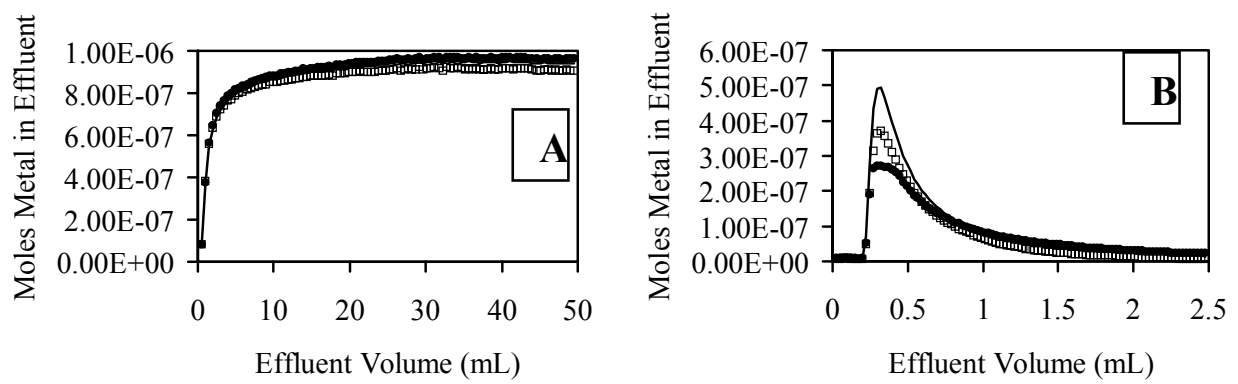

Fig. 2. Simultaneous exposure of $0.2 \mathrm{mM} \mathrm{Ni}^{2+}(\square), \mathrm{Cd}^{2+}(\bullet)$, and $\mathrm{Zn}^{2+}(-)$ to modified D. innoxia column (A) and is subsequent striping using $1.0 \mathrm{M} \mathrm{HCl}(\mathrm{B})$.

\subsection{Comparison of native and modified biomaterials}

By examining the results from the native and modified D. innoxia studies together, a hypothesis regarding the carboxyl sites contribution to the metal-ion binding process can be formulated. It was proposed, in previous studies of D. innoxia, that esterification of carboxylate sites can decrease metal uptake by as much as $40 \%$ (Drake, et al., 1996), depending on the metal. 


\subsubsection{Influent and total metal bound comparison}

By taking the ratio of metal bound for the modified and native biomaterials at each position in the sequence and averaging those ratios for both the influent metal bound and the total metal bound, the average effect of the esterification procedure on metal binding can be quantified. On average, the influent metal-ion bound decreased by $43 \%$ while the total metal bound decreased by $54 \%$. Figure 3 illustrates a further breakdown these comparisons by metal-ion position within the sequence. For total metal bound to the biomaterial, metal ion position had only a small effect in the percentage decrease in binding capacity observed in the modified biomaterial. With the first metal ion capacity dropping 52\%, the second decreased to $54 \%$ and the third decreased to $55 \%$. However, the influent metal ion capacity seems to be more effected by its position in the sequence. The first metal ion exposed demonstrated a decrease in its capacity of $52 \%$, while the second and third ions exposed decreased by only $42 \%$ and $40 \%$ respectively.

Figure 4 shows additional data regarding the influent metal bound by examining both position and specific metal ion exposed in the sequence. For nickel and zinc there was a steady decrease in the observed effect of the modification as their position in the sequence moved from first to third. Nickel was most pronounced, as the effect of the modification was decreased in capacity by $54 \%$ when nickel was the first ion exposed, $41 \%$ when it is the second, and $35 \%$ when the third. Zinc was similar as it drops from a $51 \%$ decreased in binding capacity when it was the first metal exposed, a $47 \%$ decrease when it was second, to a $41 \%$ decrease when it was third. Cadmium did not follow this pattern of decreasing effect based on position. When cadmium was the first metal exposed a decrease in binding capacity of $49 \%$ is observed, a decrease in capacity of $38 \%$ was observed when it was second, and a decrease of $44 \%$ when it metal on the column. The modified biomaterial total metal bound decreased between $49-57 \%$ depending on influent metal and position with no apparent pattern.
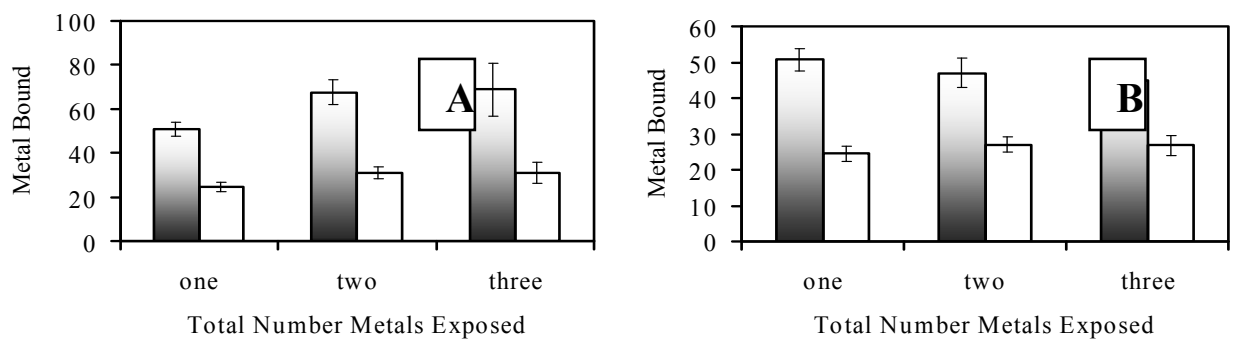

Fig. 3. Average total (A) and influent (B) metal-ion bound for native (shaded) and modified biomaterial based on number of metals exposed in series. Metal bound given in percentage metal bound.

Simultaneous exposure of the three metal-ions showed an overall decrease of $43.7 \%$ for total metal bound for the modified biomaterial. Zinc showed the largest decrease showing a $50.2 \%$ decrease in binding capacity. The modified biomaterial exhibited a loss of $43.5 \%$ for cadmium. Nickel showed the smallest effect from the modification losing $34.8 \%$ of its capacity. It should be noted that zinc, which lost the most, had the largest capacity (28.5 $\mu \mathrm{mol} \mathrm{g}^{-1}$ ), while nickel, which demonstrated the smallest effect of modification, had the smallest capacity on the native biomaterial $\left(20.3 \mu \mathrm{mol} \mathrm{g}^{-1}\right)$. 


\subsubsection{Statistical analysis}

Because of the numerous variables studied pertaining to the ability of this adsorbent to remove each of these metal ions from a flowing influent, it became imperative that statistical tools be employed to ascertain differences (and similarities) in metal binding. Variables that were tested include the esterification of carboxylate functionalities, the identity of the metal bond, the identity of the metal ion(s) displaced or removed, and the general history of a column of the biosorbent. The Student-t test was employed to test the hypothesis that the measured means of binding capacities between any two conditions were statistically the same. The criteria used for these test were a 95\% confidence level with 2 - 5 degrees of freedom.

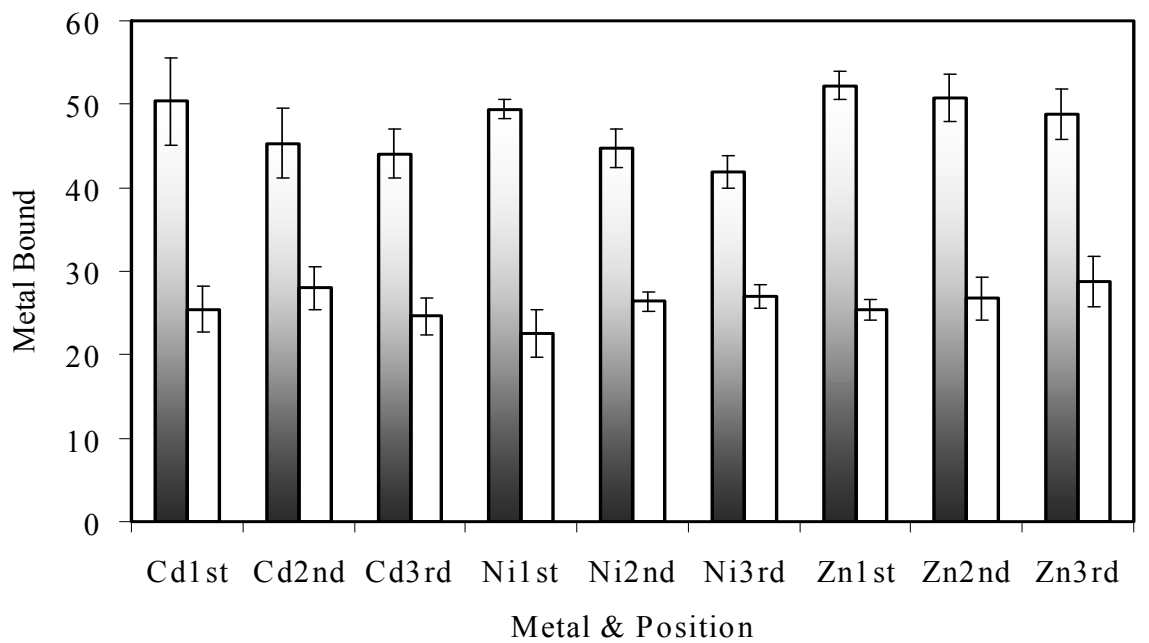

Fig. 4. Comparison of native (shaded) and modified D. innoxia columns influent-metal bound capacities. Metal bound is reported in micromoles per gram biomaterial.

To statistically treat the results presented above in the comparison of the native and esterified biomaterial, two methods of statistical analysis were used. The Student-t test was used to test the statistical difference between the amounts of metal bound to the biomaterial at each stage in the studies at each stage for the native and modified biomaterials. This would also reinforce the position that by undertaking a simple chemical modification, the binding properties of a biomaterial could be altered significantly. Also, the Student-t test was used to examine the impact of exposure order and history (e.g., whether the amount of cadmium bound to the biomaterial is statistically different for the series $\mathrm{Ni}^{2+} \Rightarrow \mathrm{Zn}^{2+} \Rightarrow \mathrm{Cd}^{2+}$ and $\left.\mathrm{Zn}^{2+} \Rightarrow \mathrm{Ni}^{2+} \Rightarrow \mathrm{Cd}^{2+}\right)$. Differences in the variances calculated for each stage were similarly evaluated using an F-test (again considering both the order of metal ion exposure and the exposure history of the material).

Table 3 summarizes the resulting statistical comparisons of the native and chemically modified D. innoxia materials using the software package 'Analysis ToolPak' within Microsoft ${ }^{\circledR}$ Excel ${ }^{\mathrm{TM}}$. Mass balance values of the influent metal bound were used in these 
calculations. A confidence limit for each was $95 \%(\alpha=0.05)$. The $t$-values presented indicate the respective probabilities that the amounts of the influent metal bound at each position were the same for both the native and modified materials. The results indicated that modification of the biomaterial did significantly decrease the binding capacities of the $D$. innoxia for each metal at each position in the sequential exposure sequence.

The F-values listed in Table 3 indicated the respective probabilities that the variances of the mean values between the native and modified biomaterials were statistically different. There were two cases a clear (>95\%) difference in the variances was indicated; 1 ) the conditions when cadmium was the first metal exposed to the column and 2) when nickel was the third metal introduced to the biosorbent material. In both cases, larger variances were observed for cadmium binding to the chemically modified material, with a percent relative standard deviation (\%RSD) of $27.22 \%$ compared to $4.86 \%$ for the native material. The binding of nickel showed similar behavior with a $25.97 \%$ RSD for its binding to the modified material in comparison to an RSD of $4.50 \%$ for the native biosorbent. This suggested sites involved in the binding of $\mathrm{Cd}^{2+}$ initially exposed to the material and those pertaining to $\mathrm{Ni}^{2+}$ binding as the third exposure metal ion were the least homogeneously affected by the chemical modification (i.e., esterification ) reaction.

\begin{tabular}{c|c|c|c} 
& Cd position 1 & Cd position 2 & Cd position 3 \\
\hline P T $\leq \mathrm{t}$ (two tail) & $1.01 \mathrm{E}-04$ & $3.72 \mathrm{E}-05$ & $3.18 \mathrm{E}-07$ \\
\hline $\mathrm{P} \mathrm{F} \leq \mathrm{f}$ (one tail) & 0.024 & 0.258 & 0.261 \\
\hline & Ni position 1 & Ni position 2 & Ni position 3 \\
\hline $\mathrm{P} \mathrm{T} \leq \mathrm{t}$ (two tail) & $1.58 \mathrm{E}-03$ & $2.73 \mathrm{E}-03$ & $2.86 \mathrm{E}-03$ \\
\hline $\mathrm{P} \mathrm{F} \leq \mathrm{f}$ (one tail) & 0.119 & 0.419 & 0.006 \\
\hline & Zn position 1 & Zn position 2 & Zn position 3 \\
\hline $\mathrm{P} \mathrm{T} \leq \mathrm{t}$ (two tail) & $3.14 \mathrm{E}-07$ & $1.66 \mathrm{E}-06$ & $8.53 \mathrm{E}-07$ \\
\hline P F $\leq \mathrm{f}$ (one tail) & 0.390 & 0.484 & 0.492
\end{tabular}

Table 3. Comparing influent metal bound at each position for the native and modified biomaterials. The $\mathrm{P} \mathrm{T} \leq \mathrm{t}$ value indicated the statistical probability that the mean values for the native and modified $D$. innoxia are the same. The $\mathrm{P} \mathrm{F} \leq \mathrm{f}$ value indicated the probability that the variances of the two means are the same.

One question that arose with regard to the sequential exposure of the sorbent to chemically similar metal ions is whether there is a statistically significant difference in the binding capacities as a function of the position of the metal in the exposure sequence (i.e., first, second, or third). This is related to the possible presence of cooperativity in the formation (or elimination) of binding sites for one metal because of the earlier binding of another metal ion to a (presumably) nearby site.

Table 4 summarizes a comparison of influent metal binding capacities within each of the studies based on metal position in the sequence using a Student t-test at $95 \%$ confidence. The $t$-values listed suggest there is no statistical difference in the amount of influent metal bound for either the native or modified biomaterials based on the position of each metal in the exposure sequence. Conversely, the F-values suggested statistical differences in the 
variances based on position in the sequence for each of four cases: For nickel, binding to the native column comparing positions 1 and 3, and positions 2 and 3;. Also for cadmium exposed to the modified column comparing positions 1 and 3 , and positions 2 and 3 . These values again suggested greater inhomogeneity in the impact of the chemical modification procedure on the sites involved in the binding of these metal ions.

\begin{tabular}{|c|c|c|c|}
\hline & 1 vs. 2 & 1 vs. 3 & 2 vs. 3 \\
\hline T Cd native & 0.739 & 0.671 & 0.985 \\
\hline T Ni native & 0.196 & 0.462 & 0.338 \\
\hline T Zn native & 0.380 & 0.707 & 0.596 \\
\hline T Cd modified & 0.241 & 0.195 & 0.912 \\
\hline T Ni modified & 0.699 & 0.686 & 0.955 \\
\hline T Zn modified & 0.567 & 0.182 & 0.428 \\
\hline F Cd native & 0.119 & 0.253 & 0.296 \\
\hline F Ni native & 0.407 & 0.035 & 0.022 \\
\hline F Zn native & 0.399 & 0.485 & 0.413 \\
\hline F Cd modified & 0.400 & 0.025 & 0.041 \\
\hline F Ni modified & 0.223 & 0.382 & 0.320 \\
\hline F Zn modified & 0.476 & 0.397 & 0.421 \\
\hline
\end{tabular}

Table 4. Comparing influent metal bound at each position. $T$ values are statistical probability that the mean metal bound at each position in sequence are the same. F values are statistical probability that their variances are the same.

Tables 5a-c provide a closer look at metal position by considering the history of metal exposure as well as position of each metal ion in the sequence. The $t$-values for all three metals indicated no statistical difference as a result of metal exposure history to the influent metal bound for either the native or modified biomaterial. The F-values again suggest statistical differences in the variances in $\mathrm{Ni}^{2+}$ binding based on exposure history. The modified biomaterial showed a difference in the variances for the comparison of the sequences $\mathrm{CdZnNi}$ with $\mathrm{ZnCdNi}$, and $\mathrm{CdNi}$ with $\mathrm{CdZnNi}$. Comparatively larger relative standard deviations (RSDs) were calculated for the sequences $\mathrm{CdNi}$ and $\mathrm{ZnCdNi}$ relative to that for the $\mathrm{CdZnNi}$ exposure sequence. A probable difference in variances for the comparison of $\mathrm{CdNi}$ with $\mathrm{CdZnNi}$, and $\mathrm{CdNi}$ with $\mathrm{ZnCdNi}$ was also observed for the native material. Under these conditions, CdNi exhibited comparatively large standard deviation relative to those of the other two conditions.

\subsubsection{Binding site matrix analysis}

Traditional statistical analysis of the metal ion binding data suggested that the chemical modification of the D. innoxia material decreased the number of binding sites significantly, thus reducing metal binding capacities for the esterified biomaterial. Additionally, statistically significant changes in the $\mathrm{Ni}^{2+}$ binding variability suggested non-uniform changes in metal-specific sites that resulted from the esterification reaction. In an effort to extract more information about the binding behavior of the biomaterial towards these three metals, a secondary method of data analysis was undertaken. 


\begin{tabular}{c|c|c|c|c|c|c} 
& 2a vs. 2b & 3a vs. 3b & 2a vs. 3a & 2a vs. 3b & 3a vs. 2b & 3b vs. 2b \\
\hline T Native & 0.955 & 0.471 & 0.607 & 0.710 & 0.830 & 0.784 \\
\hline F Native & 0.105 & 0.384 & 0.345 & 0.247 & 0.183 & 0.264 \\
\hline T Modified & 0.328 & 0.969 & 0.401 & 0.326 & 0.621 & 0.623 \\
\hline F Modified & 0.268 & 0.196 & 0.416 & 0.148 & 0.207 & 0.060
\end{tabular}

Table 5a. Effect of column history on influent cadmium bound. T values are probability that the two compared means are statistically equivalent. $F$ values are statistical probability that their variances are equivalent. $2 \mathrm{a} \rightarrow \mathrm{NiCd}, 2 \mathrm{~b} \rightarrow \mathrm{ZnCd}, 3 \mathrm{a} \rightarrow \mathrm{NiZnCd}, 3 \mathrm{~b} \rightarrow \mathrm{ZnNiCd}$.

\begin{tabular}{c|c|c|c|c|c|c} 
& 2a vs. 2b & 3a vs. 3b & 2a vs. 3a & 2a vs. 3b & 3a vs. 2b & 3b vs. 2b \\
\hline T Native & 0.483 & 0.104 & 0.326 & 0.557 & 0.345 & 0.665 \\
\hline F Native & 0.093 & 0.454 & 0.036 & 0.043 & 0.267 & 0.304 \\
\hline T Modified & 0.760 & 0.183 & 0.310 & 0.536 & 0.427 & 0.377 \\
\hline F Modified & 0.459 & 0.034 & 0.047 & 0.413 & 0.055 & 0.374
\end{tabular}

Table 5b. Effect of column history on influent nickel bound. T values are probability that the two compared means are statistically equivalent. $F$ values are statistical probability that their variances are equivalent. $2 \mathrm{a} \rightarrow \mathrm{CdNi}, 2 \mathrm{~b} \rightarrow \mathrm{ZnNi}, 3 \mathrm{a} \rightarrow \mathrm{CdZnNi}, 3 \mathrm{~b} \rightarrow \mathrm{ZnCdNi}$.

\begin{tabular}{c|c|c|c|c|c|c} 
& 2a vs. 2b & 3a vs. 3b & 2a vs. 3a & 2a vs. 3b & 3a vs. 2b & 3b vs. 2b \\
\hline T Native & 0.214 & 0.515 & 0.193 & 0.542 & 0.959 & 0.274 \\
\hline F Native & 0.939 & 0.953 & 0.736 & 0.691 & 0.553 & 0.221 \\
\hline T Modified & 0.412 & 0.327 & 0.383 & 0.440 & 0.470 & 0.354 \\
\hline F Modified & 0.094 & 0.392 & 0.357 & 0.264 & 0.157 & 0.224
\end{tabular}

Table 5c. Effect of column history on influent zinc bound. T values are probability that the two compared means are statistically equivalent. $\mathrm{F}$ values are statistical probability that their variances are equivalent. $2 \mathrm{a} \rightarrow \mathrm{CdZn}, 2 \mathrm{~b} \rightarrow \mathrm{NiZn}, 3 \mathrm{a} \rightarrow \mathrm{CdNiZn}, 3 \mathrm{~b} \rightarrow \mathrm{NiCdZn}$.

Three assumptions were made in pursuing this avenue of exploration. 1) There exist common binding sites shared between all three of the metal ions $\left(\delta_{0}\right)$. 2) For each metal ion, there exist ion-specific binding sites available only to that particular ion $(\alpha, \beta, \gamma)$. 3) For each stage in the influent solution exposure sequence, there may be enhancement or inhibition of binding due to the history of metal exposure, i.e., some level of cooperativity between sites. Making these assumptions allows for the construction of an overall binding equation for the three-metal system:

$$
\begin{gathered}
M_{\text {Bound }}=\left[a_{C d} X_{C d}+a_{N i} X_{N i}+\alpha_{Z n} X_{Z n}\right]+\left\{\beta_{C d N i} X_{C d N i}+\beta_{C d Z n} X_{C d Z n}\right. \\
\left.+\beta_{N i C d} X_{N i C d}+\beta_{N i Z n} X_{N i Z n}+\beta_{Z n C d} X_{Z n C d}+\beta_{Z n N i} X_{Z n N i}\right\}+\left(\gamma_{C d N i Z n} X_{C d N i Z n}+\right. \\
\left.\gamma_{C d Z n N i} X_{C d Z n N i}+\gamma_{N i C d Z n} X_{N i C d Z n}+\gamma_{N i Z n C d} X_{N i Z n C d}+\gamma_{Z n C d N i} X_{Z n C d N i}+\gamma_{Z n N i C d} X_{Z n N i C d}\right) \\
+\delta_{0} X_{\text {common }}
\end{gathered}
$$

From the sequential experiments, the amount of total metal bound is known for each of the above situations except for metal binding to the common binding sites, $\mathrm{X}_{\text {Common }}$. While the site-type $\mathrm{X}_{\text {Common }}$ is available for each condition, the degree to which it is available may be limited by the metal exposure history on the column and the comparative affinities of each metal for those sites. To account for this, a secondary set of data was incorporated into the 
ensuing analysis. The total metal-bound data from the simultaneous exposure of all three metals to the biomaterial were indicative of situations in which all three unique metal binding sites $\left(\mathrm{X}_{\mathrm{Cd}}, \mathrm{X}_{\mathrm{Ni}}\right.$, and $\left.\mathrm{X}_{\mathrm{Zn}}\right)$ are used along with only the common site, $\mathrm{X}_{\text {Common. This }}$ enabled the isolation of the common site from any binding enhancement or inhibition that could be attributed to metal history. By using the total amounts of each metal bound for each stage in the sequences and the amount of metal bound during the simultaneous exposure of the material to the three metals, 16 equations for metal binding can be written. The variables $\mathrm{X}_{\mathrm{Cd}}$ through $\mathrm{X}_{\text {common }}$ can have values of either 1 (the site-type is involved) or 0 (the site-type is not involved). These can then be combined into a single, 16 by 16 matrix ( $\mathbf{X}$ in Table 6) with the corresponding coefficients comprising the contents of 1 by 16 vector (c). For each stage in the sequences the common site, the individual metal-ion sites, and the corresponding sequential site will make contributions to the total metal bound. For example, the total metal bound at the sequence stage $\mathrm{Ni}^{2+} \rightarrow \mathrm{Zn}^{2+}$ can be represented by the equation:

$$
\mathrm{M}_{\mathrm{Total}}=\mathrm{a}_{\mathrm{Ni}}+\mathrm{a}_{\mathrm{Zn}}+\beta_{\mathrm{NiZn}}+\delta_{0}
$$

And the simultaneous exposure of all three metals can be represented by:

$$
\mathrm{M}_{\text {Total }}=\mathrm{a}_{\mathrm{Cd}}+\mathrm{a}_{\mathrm{Ni}}+\mathrm{a}_{\mathrm{Zn}}+\delta_{0}
$$

Where $M_{\text {Total }}$ is the total metal bound and the coefficients $(\alpha, \beta, \gamma$, and $\delta)$ indicate the

\begin{tabular}{|c|c|c|c|c|c|c|c|c|c|c|c|c|c|c|c|c|}
\hline & $\begin{array}{c}a \\
C d\end{array}$ & $\begin{array}{c}\mathbf{a} \\
\mathbf{N i}\end{array}$ & $\begin{array}{c}\mathrm{a} \\
\mathrm{Zn}\end{array}$ & $\begin{array}{c}\beta \\
\mathrm{Cd} \\
\mathrm{Ni}\end{array}$ & $\begin{array}{c}\boldsymbol{\beta} \\
\mathrm{Cd} \\
\mathrm{Ni}\end{array}$ & $\begin{array}{c}\boldsymbol{\beta} \\
\mathrm{Cd} \\
\mathrm{Ni}\end{array}$ & $\begin{array}{c}\boldsymbol{\beta} \\
\mathrm{Cd} \\
\mathrm{Ni}\end{array}$ & $\begin{array}{c}\boldsymbol{\beta} \\
\mathrm{Cd} \\
\mathrm{Ni}\end{array}$ & $\begin{array}{c}\boldsymbol{\beta} \\
\mathrm{Cd} \\
\mathrm{Ni}\end{array}$ & $\begin{array}{l}\gamma \\
\mathrm{Cd} \\
\mathrm{Ni} \\
\mathrm{Zn} \\
\end{array}$ & $\begin{array}{c}\mathrm{Y} \\
\mathrm{CdZn} \\
\mathrm{Ni}\end{array}$ & $\begin{array}{c}\gamma \\
\text { NiCd } \\
\text { Zn }\end{array}$ & $\begin{array}{c}\mathrm{Y} \\
\mathrm{NiZn} \\
\mathrm{Cd}\end{array}$ & $\begin{array}{c}\mathrm{Y} \\
\mathrm{ZnCd} \\
\mathrm{Ni}\end{array}$ & $\begin{array}{c}\mathrm{Y} \\
\mathrm{ZnNi} \\
\mathrm{Cd}\end{array}$ & $\delta_{0}$ \\
\hline $\mathrm{Cd}$ & 1 & 0 & 0 & 0 & 0 & 0 & 0 & 0 & 0 & 0 & 0 & 0 & 0 & 0 & 0 & 1 \\
\hline $\mathrm{Ni}$ & 0 & 1 & 0 & 0 & 0 & 0 & 0 & 0 & 0 & 0 & 0 & 0 & 0 & 0 & 0 & 1 \\
\hline $\mathrm{Zn}$ & 0 & 0 & 1 & 0 & 0 & 0 & 0 & 0 & 0 & 0 & 0 & 0 & 0 & 0 & 0 & 1 \\
\hline $\mathrm{CdNi}$ & 1 & 1 & 0 & 1 & 0 & 0 & 0 & 0 & 0 & 0 & 0 & 0 & 0 & 0 & 0 & 1 \\
\hline CdZn & 1 & 0 & 1 & 0 & 1 & 0 & 0 & 0 & 0 & 0 & 0 & 0 & 0 & 0 & 0 & 1 \\
\hline $\mathrm{NiCd}$ & 1 & 1 & 0 & 0 & 0 & 1 & 0 & 0 & 0 & 0 & 0 & 0 & 0 & 0 & 0 & 1 \\
\hline NiZn & 0 & 1 & 1 & 0 & 0 & 0 & 1 & 0 & 0 & 0 & 0 & 0 & 0 & 0 & 0 & 1 \\
\hline $\mathrm{ZnCd}$ & 1 & 0 & 1 & 0 & 0 & 0 & 0 & 1 & 0 & 0 & 0 & 0 & 0 & 0 & 0 & 1 \\
\hline ZnNi & 0 & 1 & 1 & 0 & 0 & 0 & 0 & 0 & 1 & 0 & 0 & 0 & 0 & 0 & 0 & 1 \\
\hline CdNiZn & 1 & 1 & 1 & 0 & 0 & 0 & 0 & 0 & 0 & 1 & 0 & 0 & 0 & 0 & 0 & 1 \\
\hline $\mathrm{CdZnNi}$ & 1 & 1 & 1 & 0 & 0 & 0 & 0 & 0 & 0 & 0 & 1 & 0 & 0 & 0 & 0 & 1 \\
\hline NiCdZn & 1 & 1 & 1 & 0 & 0 & 0 & 0 & 0 & 0 & 0 & 0 & 1 & 0 & 0 & 0 & 1 \\
\hline NiZnCd & 1 & 1 & 1 & 0 & 0 & 0 & 0 & 0 & 0 & 0 & 0 & 0 & 1 & 0 & 0 & 1 \\
\hline ZnCdNi & 1 & 1 & 1 & 0 & 0 & 0 & 0 & 0 & 0 & 0 & 0 & 0 & 0 & 1 & 0 & 1 \\
\hline ZnNiCd & 1 & 1 & 1 & 0 & 0 & 0 & 0 & 0 & 0 & 0 & 0 & 0 & 0 & 0 & 1 & 1 \\
\hline Simultaneous & 1 & 1 & 1 & 0 & 0 & 0 & 0 & 0 & 0 & 0 & 0 & 0 & 0 & 0 & 0 & 1 \\
\hline
\end{tabular}
contribution of each site-type to the total metal bound.

Table 6. Matrix representing the contributions to total metal ion bound to the immobilized D. innoxia at each stage of influent metal ion exposure in the sequential experiments. A ' 1 ' indicates a contribution to total metal binding at the particular stage, a ' 0 ' indicates the site is not involved. 


\begin{tabular}{|c|c|c|c|c|c|}
\hline (A) Coefficient | Case & Exp. $\mu$ mole/gram & 1 & 2 & 3 & 4 \\
\hline $\mathrm{Cd}$ & 25.53 & 29.58 & 62.68 & 187.30 & -6.53 \\
\hline $\mathrm{Ni}$ & 22.57 & 43.73 & 67.24 & 201.40 & -1.94 \\
\hline $\mathrm{Zn}$ & 25.40 & 53.4 & 65.29 & 211.10 & 0.36 \\
\hline $\mathrm{CdNi}$ & 30.59 & 32.75 & 116.00 & 42.71 & 0.02 \\
\hline CdZn & 31.03 & 47.59 & 112.80 & 57.55 & 1.28 \\
\hline NiCd & 30.39 & 45.32 & 128.80 & 55.28 & 12.62 \\
\hline NiZn & 29.94 & 47.78 & 113.60 & 57.74 & -3.17 \\
\hline $\mathrm{ZnCd}$ & 31.69 & 38.20 & 112.00 & 48.16 & 1.00 \\
\hline $\mathrm{ZnNi}$ & 32.07 & 56.72 & 120.30 & 66.68 & 14.49 \\
\hline CdNiZn & 31.27 & 31.87 & 167.60 & -78.40 & 0.30 \\
\hline $\mathrm{CdZnNi}$ & 28.80 & 32.57 & 162.60 & -77.70 & -0.96 \\
\hline NiCdZn & 30.93 & 44.71 & 193.60 & -65.50 & 13.17 \\
\hline NiZnCd & 28.80 & 24.26 & 156.20 & -86.00 & -4.68 \\
\hline $\mathrm{ZnCdNi}$ & 38.10 & 31.82 & 169.70 & -78.40 & 2.56 \\
\hline ZnNiCd & 28.69 & 30.96 & 167.30 & -79.30 & 6.26 \\
\hline Simultaneous & 41.72 & 36.41 & 191.70 & 410.20 & -30.40 \\
\hline
\end{tabular}

\begin{tabular}{c|c|c|c|c|c} 
(B) Coefficient | Case & Exp. $\mu$ mole/gram & 1 & 2 & 3 & 4 \\
\hline $\mathrm{Cd}$ & 50.35 & 45.60 & 756.48 & 334.45 & -16.11 \\
\hline $\mathrm{Ni}$ & 49.42 & 38.00 & 268.98 & 326.85 & -11.68 \\
\hline $\mathrm{Zn}$ & 52.27 & 46.14 & -202.78 & 334.99 & -7.64 \\
\hline $\mathrm{CdNi}$ & 70.31 & 50.81 & 557.30 & 90.26 & -8.63 \\
\hline $\mathrm{CdZn}$ & 69.39 & 55.57 & 82.16 & 95.02 & -3.49 \\
\hline $\mathrm{NiCd}$ & 61.10 & 46.83 & 553.32 & 86.28 & -8.19 \\
\hline $\mathrm{NiZn}$ & 67.60 & 50.40 & 76.99 & 89.85 & 6.78 \\
\hline $\mathrm{ZnCd}$ & 59.34 & 54.47 & 560.96 & 93.92 & 3.00 \\
\hline $\mathrm{ZnNi}$ & 69.16 & 52.05 & 78.64 & 91.50 & 8.20 \\
\hline $\mathrm{CdNiZn}$ & 74.07 & 39.35 & -102.89 & -128.61 & -4.86 \\
\hline $\mathrm{CdZnNi}$ & 73.12 & 40.19 & -102.05 & -127.77 & 0.24 \\
\hline $\mathrm{NiCdZn}$ & 67.28 & 37.77 & -104.47 & -130.19 & -2.02 \\
\hline $\mathrm{NiZnCd}$ & 66.05 & 37.36 & -104.88 & -130.60 & 1.84 \\
\hline $\mathrm{ZnCdNi}$ & 64.08 & 40.10 & -102.14 & -127.86 & 4.35 \\
\hline $\mathrm{ZnNiCd}$ & 68.13 & 39.51 & -102.73 & -128.45 & 3.77 \\
\hline Simultaneous & 72.87 & 40.68 & -1505.70 & 673.19 & -50.24
\end{tabular}

Table 7. Modified (A) and Native (B) columns experimental and calculated total metals bound, Case 1: All unique single metal bonds are included when appropriate in the sequential case and only all three unique sites along with the common site for the simultaneous case. Case 2: Same as case 1 except for the simultaneous all three, three metal binding site types are active along with the unique sites and common site. Case 3: The unique metal coefficients are not included in the simultaneous portion of the matrix calculation. Case 4: The unique metal coefficients are only included when they are the first metal on the column 
The system can then be represented by the matrix equation:

$$
[\mathbf{M}]=[\mathbf{c}][\mathbf{X}]
$$

with [A] is a 1 by 16 vector containing the total amount of metal bound for each situation, [c] is a 1 by 16 vector containing the contribution coefficients for each site type, and [X] is the 16 by 16 matrix describing the types of binding that may be taking place. For example, the row in the matrix $[\mathbf{X}]$ corresponding to the previous example $(\mathrm{Ni} \rightarrow \mathrm{Zn})$ would be $\left[\begin{array}{lllllll}0 & 1 & 0 & 0 & 0 & 1 & 0\end{array}\right.$ $\left.\begin{array}{llllllll}0 & 0 & 0 & 0 & 0 & 0 & 0 & 1\end{array}\right]$. Both [M] and [ $\left.\mathbf{X}\right]$ are therefore known or determined experimentally. The contribution coefficient matrix, [c], can then be calculated by solving the multivariate equation.

$$
[\mathbf{M}][\mathbf{X}]^{\mathrm{T}}\left([\mathbf{X}][\mathbf{X}]^{\mathrm{T}}\right)^{-1}=[\mathbf{c}]
$$

The superscripts $\mathrm{T}$ and -1 designate the corresponding transposed and inverted matrices, respectively.

Four matrices were examined using this methodology. The matrix presented in Table 6 includes all of the unique single metal bonds, where appropriate, in the sequential case, and only the three unique sites plus the common site for the simultaneous case. Tables $7 \mathrm{a}$ and $\mathrm{b}$ list the experimentally determined total amounts of metal bound with the predicted amounts from four separate theoretical calculations. Case 1 shows the results from the calculations using the matrix shown in Table 6. Case 2 is the same matrix as case 1 except for the simultaneous row, which now includes all three, three-metal binding sites (coefficients $\gamma_{\mathrm{NiZnCd}} \mathrm{YZnCdNi}_{\mathrm{N}}$ and $\mathrm{YZnNiCd}$ ) along with the unique and common sites. Case 3 differs from case 2 by eliminating the unique sites from the simultaneous portion of the matrix. Case 4 is distinguished by only including the unique metal site type when the metal is the first metal introduced to the column.

Upon examining the results presented in Tables $7 \mathrm{a}$ and $\mathrm{b}$, it was evident that case 1 best approximated the experimental results. Figure 5 illustrates the values of the contribution coefficients for both the native and the modified (shaded) D. innoxia total metal bound studies.

The most striking and least surprising result of this analysis was the contribution the common site $\left(\delta_{0}\right)$ made to overall binding for both the native and the modified biomaterial. Also noteworthy, was the series of positive coefficients present in the two metal ion systems. For both the native and modified biomaterials, it appears that the presence of a metal ion enhanced the biomaterial's binding capacity. The lone exception to this was the impact of the NiZn sequence on the modified material.

The native biomaterial exhibited slight positive coefficients for the unique $\mathrm{Cd}^{2+}$ and $\mathrm{Zn}^{2+}$ sites and a moderate apparent inhibition for $\mathrm{Ni}^{2+}$. All binary combinations of metal ions exposed to the native biomass resulted in moderate positive coefficient values. The tertiary combinations all yielded moderately negative values. This does not necessarily indicate an absolute inhibition of binding, but can be interpreted in terms of relative inhibition effects. Review of the experimental data listed in Table $7 \mathrm{~b}$ reveals single metal values as all near 50 $\mu \mathrm{mol} \mathrm{g}{ }^{-1}$ (average 50.68). Comparatively, binary combinations ranged from $60-70 \mu \mathrm{mol} \mathrm{g}-1$ (average 66.15), an increase of 15 while tertiary combinations ranged from $65-75 \mu \mathrm{mol} \mathrm{g}-1$ (average 68.78), an increase which may not be statistically significant. This suggests some degree of cooperativity in metal-ion binding while the primary mechanism of metal ion binding is simple electrostatic (i.e., the dominance of the common sites). 


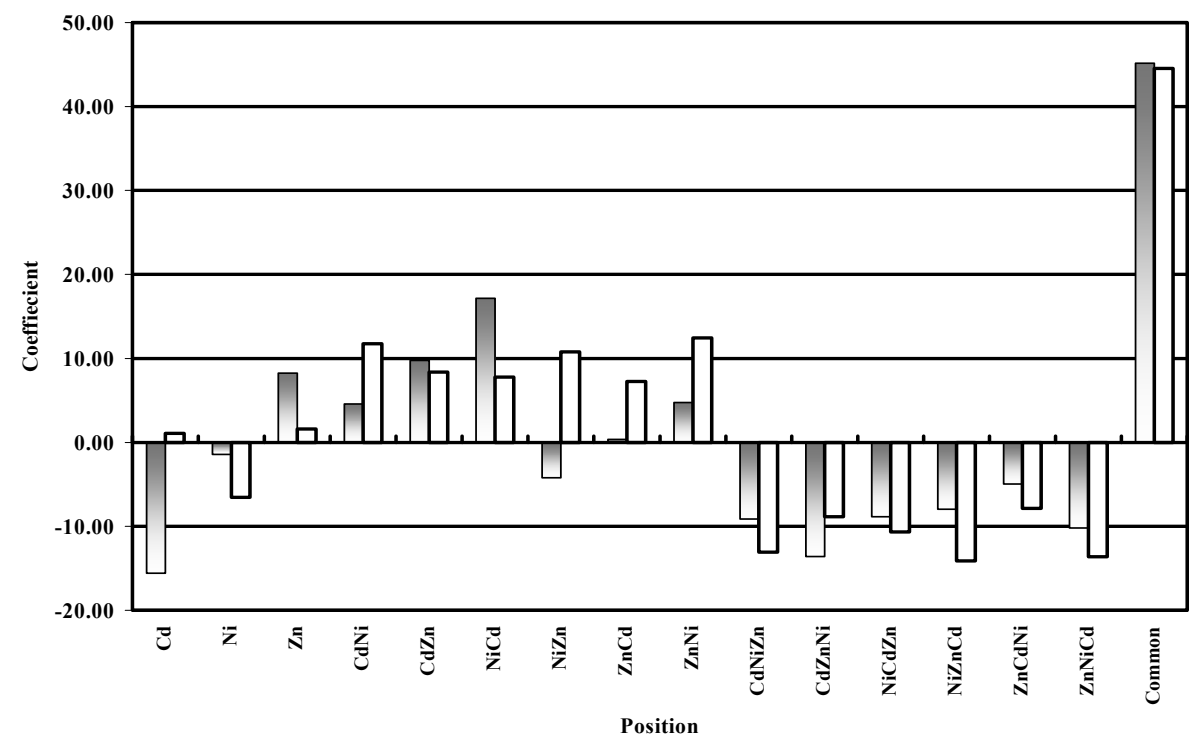

Fig. 5. Comparison of native and modified (shaded) D. innoxia matrix coefficients.

\begin{tabular}{c|c|c|c} 
Binding Sites & Coefficient & Native Material & Modified Material \\
\hline $\mathrm{Cd}$ & $\mathrm{a}_{\mathrm{Cd}}$ & 1.07 & -15.57 \\
\hline $\mathrm{Ni}$ & $\mathrm{a}_{\mathrm{Ni}}$ & -6.53 & -1.42 \\
\hline $\mathrm{Zn}$ & $\mathrm{a}_{\mathrm{Zn}}$ & 1.61 & 8.25 \\
\hline $\mathrm{CdNi}$ & $\beta_{\mathrm{CdNi}}$ & 11.74 & 4.59 \\
\hline $\mathrm{CdZn}$ & $\beta_{\mathrm{CdNi}}$ & 8.36 & 9.76 \\
\hline $\mathrm{NiCd}$ & $\beta_{\mathrm{CdNi}}$ & 7.76 & 17.16 \\
\hline $\mathrm{NiZn}$ & $\beta_{\mathrm{CdNi}}$ & 10.79 & -4.20 \\
\hline $\mathrm{ZnCd}$ & $\beta_{\mathrm{CdNi}}$ & 7.26 & 0.37 \\
\hline $\mathrm{ZnNi}$ & $\beta_{\mathrm{CdNi}}$ & 12.44 & 4.74 \\
\hline $\mathrm{CdNiZn}$ & $\gamma_{\mathrm{CdNiZn}}$ & -13.07 & -9.13 \\
\hline $\mathrm{CdZnNi}$ & $\gamma_{\mathrm{CdZnNi}}$ & -8.85 & -13.60 \\
\hline $\mathrm{NiCdZn}$ & $\gamma_{\mathrm{NiCdZn}}$ & -10.67 & -8.86 \\
\hline $\mathrm{NiZnCd}$ & $\gamma_{\mathrm{NiZnCd}}$ & -14.11 & -7.95 \\
\hline $\mathrm{ZnCdNi}$ & $\gamma_{\mathrm{ZnCdNi}}$ & -7.84 & -4.96 \\
\hline $\mathrm{ZnNiCd}$ & $\gamma_{\mathrm{CdNiZn}}$ & -13.61 & -10.19 \\
\hline $\mathrm{Common}$ & $\delta_{0}$ & 44.53 & 45.15
\end{tabular}

Table 8. Coefficient values for both the native and modified D. innoxia metal ion binding sequences.

The modified biomaterial's coefficients behaved in a similar manner as the native. The single metal coefficients for $\mathrm{Cd}^{2+}$ and $\mathrm{Ni}^{2+}$ were both negative $\left(\mathrm{Ni}^{2+}\right.$ slightly, $\mathrm{Cd}^{2+}$ moderately) 
while $\mathrm{Zn}^{2+}$ was moderately positive. All of the binary combinations were moderately positive except for NiZn, which was moderately negative, and $\mathrm{ZnCd}$, which was only slightly positive. The tertiary combinations were as on the native biomaterial, all moderately negative. Again, this only reflects relative inhibition of metal ion binding. The data listed in Table 7a reveals single metal bound values were all about $25 \mu \mathrm{mol} \mathrm{g} \mathrm{g}^{-1}$ (average 24.5). These are compared to those for the binary combinations which ranged from $30-32 \mu \mathrm{mol} \mathrm{g}-1$ (average 31.0), an increase of 6 . Similarly to the native material, the tertiary combinations ranged from 29 - $39 \mu \mathrm{mol} \mathrm{g}^{-1}$ (average 31.1), a slight increase which may not be statistically significant. This again suggested that some degree of cooperativity in binding with the primary binding mechanism involving electrostatic attractions.

\section{Conclusions}

Carboxylate groups are important functionalities for metal ion adsorption for the biomaterial Datura innoxia. Esterification of these functionalities was observed to reduce metal binding capacity $30-40 \%$. Three metals of similar binding affinity to the biomaterial $\left(\mathrm{Cd}^{2+}, \mathrm{Ni}^{2+}\right.$, and $\left.\mathrm{Zn}^{2+}\right)$ were exposed sequentially to both the native esterified biomaterials immobilized within a polysilicate matrix. Removal of surface carboxylates significantly impacted the binding of each metal ion and the impact of each metal bound on the binding of the others. A model involving at least 16 binding sites for these metal ions revealed a majority of binding to involve species-independent or common sites and the presence of cooperativity for some metal-ion binding environments

\section{Acknowledgements}

The authors wish to acknowledge the financial support of the Waste-management Education and Research Consortium funded by the US Department of Energy through New Mexico State University.

\section{References}

Davis, T.A.; Volesky, B.; Mucci, (2003) A. A Review of the Biochemistry of Heavy Metal Biosorption by Brown Algae. Water Research vol.37, No. 18 (November 2003) pp. 4311-4330 ISSN: 0043-1354.

Drake, L.R.;.Rayson, G. D. (1996) Plant Materials for Metal Selective Binding and Preconcentration Analytical Chemistry, vol. 68, no. 1 ( Jauary 1996), pp. 22A-27A. ISSN 0003-2700

Drake, L.R.; Lin, S.; Rayson, G.D. (1996) Chemical Modification and Metal Binding Studies of Datura innoxia. Environmental Science and Technology, vol. 30, no. 1 (January 1996) pp. 110-114. ISSN 0013 936X

Drake, L.R.; Hensman, C.E.; Lin, S.; Rayson, G.D.; Jackson, P.J. (1997) Characterization of Metal Ion Binding Sites on Datura innoxia by Using Lanthanide Ion Probe Spectroscopy. Applied Spectroscopy, vol. 51, no. 10 (October 1997) pp. 1476-1483. ISSN 0003-7028 
Fourest, E.; Volesky, B. (1996) Contribution of Sulfonate Groups and Alginate to Heavy Metal Biosroption by Dry Biomass of Sargassum fluitans Environmental Science and Technology vol. 30, no. 1 (January 1996) pp. 277-282. ISSN 0013 936X

Gardea-Torresdey, J.L.; Tiemann, K.J.; Gamez, G.; Dokken, K. (1999) Effects of Chemical Competition for Multi-metal Binding by Medicago sativa (alfalfa), Journal of Hazardous Materials, vol. 69, no. 1, (October 1999) pp. 41-51 ISSN: 0304-3894.

Gardea-Torresdey, J.L.; Arteaga, S.; Tiemann, K.J.; Chinaelli, R.; Pingatore, N.; Mackay, W., (2001) Absorption of Copper(II) by Creosote Bush (Larrea tridentata): Use of Atomic and X-ray Absorption Spectroscopy, Environmental Toxology and Chemistry, vol. 20, no. 11 (November 2001) pp. 2572-2579 ISSN: 0730-7268.

Jackson, P.J.; Anderson, W.L;. DeWitt, J.G.; Ke, H.-Y.D.; Kuske, C.R.; Moncrief, R.M.; Rayson G.D., (1993) Accumulation of Toxic Metal Ions on Cell Walls of Datura innoxia Suspension Cell Cultures In Vitro Cellular Developmental Biology-Plant, vol. 29P, no. 4 October 1993) pp. 220-226 ISSN: 1054-5476.

Kelley, C.; Mielke, R.E.; Dimaquibo, D.; Curtis, A.J.; DeWitt, J.G. (1999) Adsorption of Eu(III) onto Roots of Water Hyacinth. Environmental Science and Technology, vol. 33, no. 9 (May 1 1999) pp. 1430-1443. ISSN 0013 936X

Lin, S.; Drake, L.; Rayson, G. D. (1996) Applications of Frontal Affinity Chromatography to the Study of Interactions Between Metal Ions and a Complex Biomaterial Analytical Chemistry, vol. 68, no. 23 (December 1 1996) pp. 4087-4093. ISSN 0003-2700

Lin, S.; Drake, L. R.; Rayson, G. D. (2002) Affinity Distributions of Lead Ion Binding to an Immobilized Biomaterial Derived from Cultured Cells of Datura innoxia Advances in Environmental Research vol. 6, no. 4 (October 2002) pp. 523-532 ISSN: 1093-0191.

Majidi, V.; Laude, D.A.; Holcombe, J.A. (1990) Investigation of the Metal Algae Binding-Site with Cd-113 Nuclear-Magnetic-Resonance. Environmental Science and Technology, vol. 24, no. 9 (September 1990) pp. 1309-1312. ISSN 0013 936X

Riddle, S.G.; Ran, H.H.; DeWeitt, J.G.; Andrews, J.C. (2002) Field, Laboratory, and X-ray Absorption Spectroscopic Studies of Mercury Accumulation by Water Hyacinths. Environmental Sciency and Technology, vol. 36, no. 9 (May 1 2002) pp. 1965-1970. ISSN 0013 936X

Serna, D.D.; Moore, J.L.; Rayson, G.D. (2010) Site-Specific Binding Isotherms to a Datura innoxia Biosorbent. Journal of Hazardous Materials, vol. 173, no. 1-3 (January 15 2010) pp.409-414 ISSN: 0304-3894.

Stark P. C.;. Rayson, G. D. (2000) Comparison of Metal Ion Binding to Immobilized Biogenic Materials in a Flowing System, Advances in Environmental Research, vol. 4, no. 2 (May 2000) pp. 113-122 ISSN: 1093-0191.

Volesky, B. (2000) Biosorption of Heavy Metals: Methodology Example of Uranium Removal in Biologische Abwasserreinigung, vol. 14, no. , pp. 17-37.

Williams, P.A.; Rayson, G. D. (2003) Simultaneous Multi-element Detectino of Metal Ions Bound to a Datura innoxia Material, Journal of Hazardous Materials vol. B99, no. 3 (May 30 2003) pp. 277-285 ISSN: 0304-3894.

Xia, H.; Rayson, G. D. (1998) Investigation of Al binding to a Datura innoxia material using ${ }^{27} \mathrm{Al}$ NMR Environmental Science and Technology, vol. 32, no. 18 (September 15 1998) pp. 2688-2692. ISSN 0013 936X 
Xia, H.; Rayson, G.D., (2002) ${ }^{113}$ Cd NMR Spectrometry Of Cd Binding Sites On Algae And Higher Plant Tissues, Advances in Environmental Research, vol. 7, no. 1 (November 2001) pp. 157-167 ISSN: 1093-0191.. 


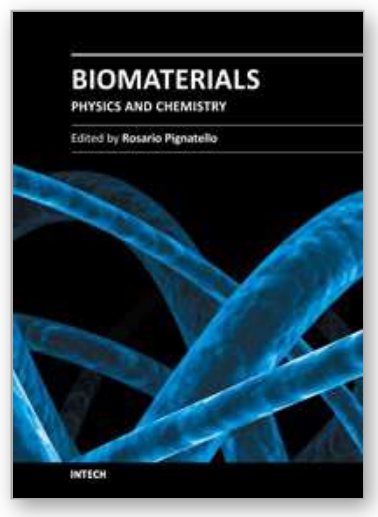

\author{
Biomaterials - Physics and Chemistry \\ Edited by Prof. Rosario Pignatello
}

ISBN 978-953-307-418-4

Hard cover, 490 pages

Publisher InTech

Published online 14, November, 2011

Published in print edition November, 2011

These contribution books collect reviews and original articles from eminent experts working in the interdisciplinary arena of biomaterial development and use. From their direct and recent experience, the readers can achieve a wide vision on the new and ongoing potentialities of different synthetic and engineered biomaterials. Contributions were selected not based on a direct market or clinical interest, but based on results coming from very fundamental studies. This too will allow to gain a more general view of what and how the various biomaterials can do and work for, along with the methodologies necessary to design, develop and characterize them, without the restrictions necessarily imposed by industrial or profit concerns. The chapters have been arranged to give readers an organized view of this research area. In particular, this book contains 25 chapters related to recent researches on new and known materials, with a particular attention to their physical, mechanical and chemical characterization, along with biocompatibility and hystopathological studies. Readers will be guided inside the range of disciplines and design methodologies used to develope biomaterials possessing the physical and biological properties needed for specific medical and clinical applications.

\title{
How to reference
}

In order to correctly reference this scholarly work, feel free to copy and paste the following:

Gary D. Rayson and Patrick A. Williams (2011). Comparative Metal lon Binding to Native and Chemically Modified Datura innoxia Immobilized Biomaterials, Biomaterials - Physics and Chemistry, Prof. Rosario Pignatello (Ed.), ISBN: 978-953-307-418-4, InTech, Available from:

http://www.intechopen.com/books/biomaterials-physics-and-chemistry/comparative-metal-ion-binding-tonative-and-chemically-modified-datura-innoxia-immobilized-biomateri

\section{INTECH}

open science / open minds

\section{InTech Europe}

University Campus STeP Ri

Slavka Krautzeka 83/A

51000 Rijeka, Croatia

Phone: +385 (51) 770447

Fax: +385 (51) 686166

www.intechopen.com

\section{InTech China}

Unit 405, Office Block, Hotel Equatorial Shanghai

No.65, Yan An Road (West), Shanghai, 200040, China

中国上海市延安西路65号上海国际贵都大饭店办公楼405单元

Phone: +86-21-62489820

Fax: +86-21-62489821 
(C) 2011 The Author(s). Licensee IntechOpen. This is an open access article distributed under the terms of the Creative Commons Attribution 3.0 License, which permits unrestricted use, distribution, and reproduction in any medium, provided the original work is properly cited. 